\title{
Synthesis and characterization of novel olefin complexes of palladium( 0 ) with chelating bis(N-heterocyclic carbenes) as spectator ligands
}

\author{
T. Scattolin ${ }^{\text {a }}$, L. Canovese ${ }^{\text {a,*, }}$ F. Visentin ${ }^{a}$, C. Santo ${ }^{a}$, N. Demitri ${ }^{\text {b }}$ \\ a Dipartimento di Scienze Molecolari e Nanosistemi, Università Ca' Foscari, Venice, Italy \\ ${ }^{\mathrm{b}}$ Elettra - Sincrotrone Trieste, S S 14 Km 1635 in Area Science Park, 34149 Basovizza, Trieste, Italy
}

\section{A R T I C L E I N F O}

\section{Article history:}

Received 24 May 2018

Accepted 3 August 2018

Available online 12 August 2018

\section{Keywords:}

Chelating N-heterocyclic carbenes

Palladium(0) complexes

Palladium olefin complexes

Solid-state structure

Synthesis and characterization

\begin{abstract}
A B S T R A C T
We have synthesized several novel palladium( 0 ) olefin complexes stabilized by strong $\sigma$-donating bis-chelating carbene ligands characterized by one or two $\mathrm{CH}_{2}$ spacers and electron-withdrawing olefins. Although it appears obvious that the $\sigma$-donating carbenes and electron-withdrawing olefins should cooperate in the stabilization of the ensuing complexes, the limit of their coexistence was not hitherto clear. On the basis of previously measured stabilizing capability of the olefins toward $\operatorname{Pd}(0)$ complexes we were able to synthesize ten complexes (nine new and one synthesized by a different protocol from that of the literature). The less electron-withdrawing olefin capable of stabilizing the complex was dimethylfumarate. However, the most interesting results were obtained with the (Z)-1,2-bis(p-tolylsulfonyl)ethene (cis-sulf) which instantly isomerizes upon coordination and in the case of the derivative bearing the olefin tetramethyl ethene-1,1,2,2-tetracarboxylate (tmetc) whose decomposition in $\mathrm{CD}_{2} \mathrm{Cl}_{2}$ yields the saturated tetramethyl ethane-1,1,2,2-tetracarboxylate $\left(D_{2}\right)$. The solid-state structure of the complex 4d bearing the bis-carbene 1,1'-dibenzyl-3,3'methylenediimidazol-2,2'-diylidene and the olefin (E)-1,2-bis(p-tolylsulfonyl)ethene (trans-sulf) was also determined.
\end{abstract}

(c) 2018 Elsevier Ltd. All rights reserved.

\section{Introduction}

The stability and performance of homogeneous catalysts throughout the turnover processes is strongly influenced by the nature of the ligands and metal. In this respect thanks to its redox potentials which allow an easy shift between two quite stable oxidation states, $\operatorname{Pd}(\mathrm{II})$ and $\operatorname{Pd}(0)$ catalysts or pro-catalysts [1] have been very frequently studied and used mainly in the field of the homo- and hetero-cross coupling [2].

Beside the widespread use of phosphines as stabilizing ligands, most recently, NHC ligands have become quite popular in the preparation of stable palladium catalysts [3] owing to their intrinsic stability toward heat, moisture and air and their low toxicity [4].

As a matter of fact, their strong donating capability can compete with other commonly used ligands in the stabilization of their complexes whereas the steric hindrance of the NHC can be easily tuned-up by an accurate choice of the substituents at the imidazolic nitrogen [5], as was at once apparent after the synthesis of the first stable NHC derivatives [6].

\footnotetext{
* Corresponding author.

E-mail address: cano@unive.it (L. Canovese).
}

In particular, since the 90s bis-carbene palladium complexes have been widely investigated and many catalysts displaying remarkable enantioselectivity synthesized [7].

However, the $\sigma$-donor NHC ligands, strongly conflict with the electron density of the olefin stabilized $\mathrm{d}^{10}$ complexes and therefore very few species of this type are described in the literature [8]. Among them, only few $\operatorname{Pd}(0)$ olefin complexes bearing chelating bis-carbenes as spectator ligands, stabilized by the strongly withdrawing maleic anhydride were synthesized by Elsevier and co-workers [9].

We have been involved in studies dealing with the synthesis and reactivity of $\operatorname{Pd}(0)$ olefin complexes for many years. In particular, we were able to correlate the mutual stability imparted by the olefin to $\operatorname{Pd}(0)$ and $\operatorname{Pt}(0)$ complexes stabilized by homogeneous spectator ligands and eventually summarize the general trend that is reported in Scheme 1 [10].

$$
\left[\left(\mathrm{L}-\mathrm{L}^{\prime}\right) \operatorname{pd}\left(\eta^{2}-\text { olefin }_{1}\right)\right]+\text { olefin }_{2} \rightleftharpoons\left[\left(\mathrm{L}-\mathrm{L}^{\prime}\right) \operatorname{pd}\left(\eta^{2}-\text { olefin }_{2}\right)\right]+\text { olefin }_{1}
$$

It was therefore interesting for us to try and synthesize chelating $\mathrm{NHC} \operatorname{Pd}(0)$ olefin complexes and establish which olefin of the cited ones could be coupled with the strong $\sigma$-character of the bis-carbene ligand. In this respect we have successfully 


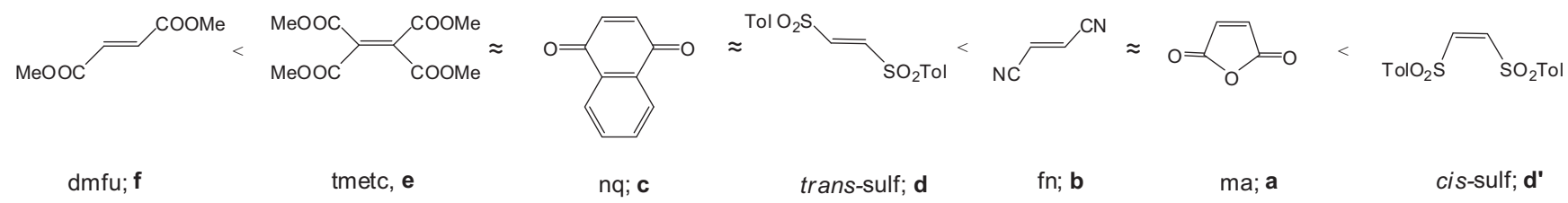

Scheme 1. Stability rank imparted to $\mathrm{Pd}(0)$ complexes by the deactivated olefins based on the equilibrium constant of the reaction.

synthesized the $\operatorname{Pd}(0)$ derivatives bearing the chelating $\mathrm{NHC}$ and olefin described in the following Scheme 2.

\section{Results and discussion}

\subsection{General remarks}

The complexes 1a-c [11], 1d-d' [12], 1e [13] and the imidazolium salts [7c] were synthesized according to published procedures. The silver carbene complexes 2, 3 were obtained by adding in the dark $\mathrm{Ag}_{2} \mathrm{O}$ in slight stoichiometric excess to a methanol solution of the corresponding imidazolium salt [14]. The reaction progress was monitored by the progressive disappearance of the solid $\mathrm{Ag}_{2} \mathrm{O}$, whereas the ${ }^{1} \mathrm{H}$ and ${ }^{13} \mathrm{C}$ NMR spectra of the isolated derivatives and in particular the disappearance of the signal ascribable to the imidazolium proton within 9-10 ppm confirm the formation of the expected species (See Fig. S1, Supplementary Material). Derivatives 1a-e and 1f were chosen as starting

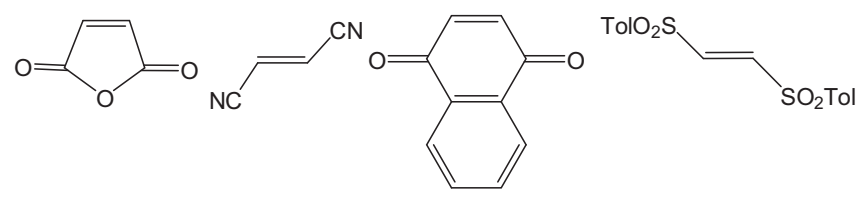

ma; a

fn; $b$ complexes thanks to their remarkable stability coupled with the peculiar reactivity which make easy the displacement of the spectator ligands in many exchange reactions [15]. The trans-metalation reaction between complexes of type $\mathbf{1}$ and silver carbenes yields the palladium carbene olefin derivatives according to Scheme 3 .

The type $\mathbf{4}$ and $\mathbf{5}$ complexes were characterized by elemental analysis, IR, ${ }^{1} \mathrm{H}$ and ${ }^{13} \mathrm{C}$ NMR spectrometry. In the case of complex 4d the solid state structure was also determined by X-ray diffractometry.

\subsection{Maleic anhydride and fumaronitrile complexes $\mathbf{4 a}-\mathbf{4 b}$ and $\mathbf{5 a}-\mathbf{5 b}$}

The complexes of type $\mathbf{4}$ and $\mathbf{5}$ were obtained by reacting in $\mathrm{CH}_{2} \mathrm{Cl}_{2}$ the starting complexes $\mathbf{1 a}$ or $\mathbf{1 b}$ with the silver derivatives $\mathbf{2}$ or $\mathbf{3}$ according to the protocol reported in Scheme 3. The complexes $\mathbf{4 a - b}$ and $\mathbf{5 a - b}$ were all synthesized under similar experimental conditions (RT, reaction time: 30'). Although the synthesis of complex 4a was already published we have chosen

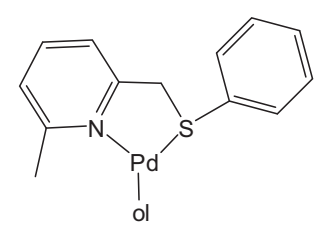

$\mathrm{ol}=\mathrm{ma} ; \mathbf{1 a}$

$\mathrm{ol}=\mathrm{fn} ; \mathbf{1 b}$

ol $=$ nq; $1 \mathrm{c}$

$\mathrm{ol}=$ cis-solf; $1 \mathbf{d}^{\prime}$

ol = trans-solf; $1 \mathbf{d}$

$\mathrm{ol}=$ tmetc $; 1 \mathrm{e}$

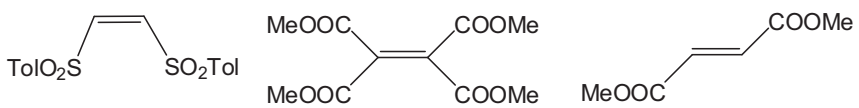

cis-sulf; d'

tmetc, e

dmfu; $\mathbf{f}$
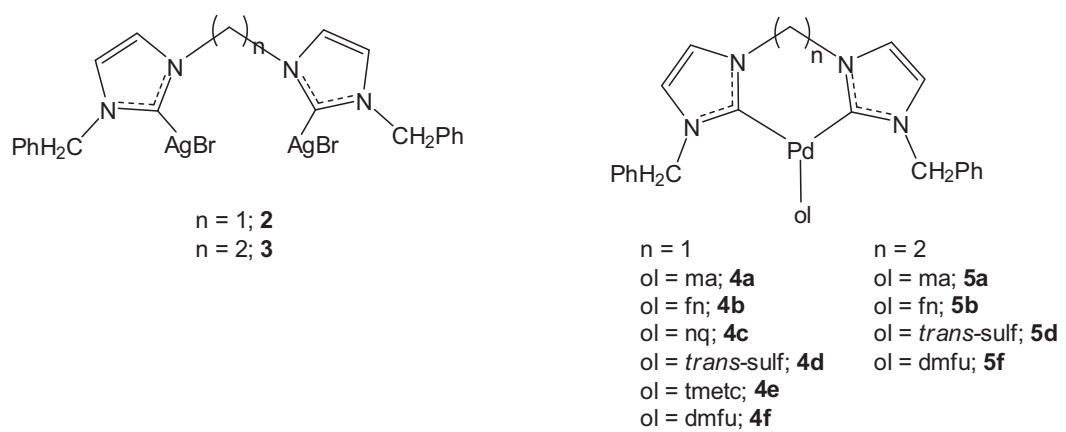

Scheme 2. Starting ligands, silver intermediates and $\operatorname{Pd}(0)$ olefin bis-carbene complexes. 

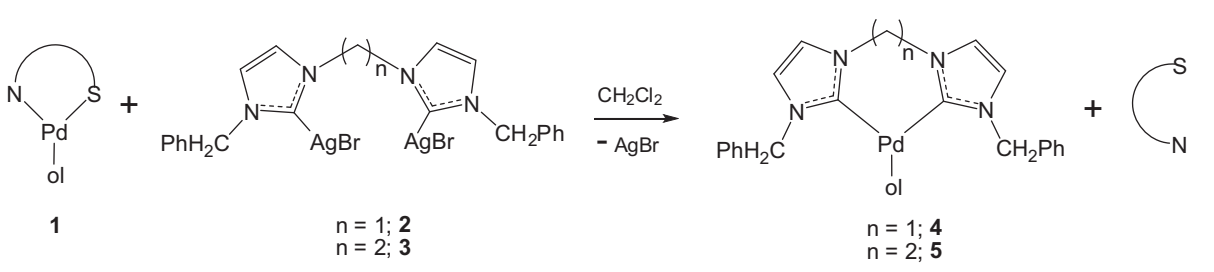

Scheme 3. Reaction of formation of the complexes of type $\mathbf{4}$ and $\mathbf{5 .}$

to follow our synthetic approach which in this case gave similar selectivity and yield than those previously proposed by Elsevier and co-workers [9]. Moreover, it is worth noting that the versatility of our protocol summarized in Scheme 3 was exploited in the synthesis of all the other complexes reported in this paper. Thus complexes $\mathbf{4 b}$ and $\mathbf{5 a}$, $\mathbf{b}$ were separated from the reaction mixture and characterized.

The relevant spectra of complexes $4 \mathbf{4 a}, \mathbf{b}$ and $\mathbf{5 a} \mathbf{a}-\mathbf{b}$ are reported in Supplementary Material Figs. S2a-c and S3a-c and the complete NMR characterization in the Section 5.

In particular, the ${ }^{1} \mathrm{H}$ NMR spectra of the maleic anhydride (ma) derivatives $4 \mathbf{a}$ and $\mathbf{5 a}$ are comparable and characterized by one singlet at ca. 3.6-3.7 ppm due to the olefin protons of ma, two doublets at ca. 6.9-7.2 ppm due to imidazole protons, one AB system at 5.3-5.4 ppm of methylenic protons of the imidazole benzyl substituents and finally one $\mathrm{AB}$ system at ca. $5.9 \mathrm{ppm}$ or one multiplet at ca. $4.7 \mathrm{ppm}$ ascribable to the protons of the spacers of complex 4a or 5a, respectively. The ${ }^{13} \mathrm{C}$ NMR spectra display the signal of carbene carbon at ca. 184-186 ppm, the carbonyl carbon at ca. $175 \mathrm{ppm}$ and the olefin carbon at ca. $39 \mathrm{ppm}$. The benzyl $-\mathrm{CH}_{2}-$ resonate at ca. 55 and $65 \mathrm{ppm}$ whereas the carbons of the spacers at 50 or 49 ppm in the case of $\mathbf{4 a}$ or $\mathbf{5 a}$, respectively.

As for the ${ }^{1} \mathrm{H}$ NMR characterization of fumaronitrile ( $\mathrm{fn}$ ) derivatives $\mathbf{4 b}$ and $\mathbf{5 b}$ which not surprisingly again display comparable spectra, the most relevant signals are a singlet at ca. $2.3-2.5 \mathrm{ppm}$ related to the olefin protons, a couple of doublets within 6.8 and $7.2 \mathrm{ppm}$ of the imidazole protons, one $\mathrm{AB}$ system for the methylene- $\mathrm{CH}_{2}-\mathrm{Ph}$ protons. The presence of a singlet at ca. $6 \mathrm{ppm}$ in the case of complex $4 \mathbf{b}$ (spacer $\mathrm{N}-\mathrm{CH}_{2}-\mathrm{N}$ ) and of one AB system within 4.6-5.0 ppm for the complex $\mathbf{5 b}$ (spacer $\mathrm{N}-\mathrm{CH}_{2}-$ $-\mathrm{CH}_{2}-\mathrm{N}$ ) completes the assignment of the protons.

The ${ }^{13} \mathrm{C}$ NMR spectra exhibit the signals ascribable to carbon of the coordinated carbene, of the nitrile $(\mathrm{CN})$ and of the benzyl $\left(-\mathrm{CH}_{2}-\mathrm{Ph}\right)$ groups at ca. 186,127 , and $55 \mathrm{ppm}$, respectively. The signals related to the olefin at ca. $13 \mathrm{ppm}$, those at $63(\mathbf{4 b})$ and at 49 ppm (5b) ascribable to the carbons of the spacers and those of the imidazole carbons within 119-122 ppm, complete the NMR characterization.

\subsection{Naphthoquinone complex $\mathbf{4 c}$}

Owing to the instability in solution of the naphthoquinone (nq) derivatives following the protocol of Scheme 3 we were able to synthesize at $223 \mathrm{~K}$ and characterize at $243 \mathrm{~K}$ only complex 4c. As can be deduced from the ${ }^{1} \mathrm{H}$ and ${ }^{13} \mathrm{C}$ NMR spectra of complex $\mathbf{4 c}$ reported in Supplementary Material (Fig. S4a-b) the olefin protons resonate at ca. $5.0 \mathrm{ppm}$, whereas at 5.2-5.8 ppm the AB system related to the $\mathrm{CH}_{2}$-Ph protons can be traced back. The singlet at ca. $5.6 \mathrm{ppm}$ and a couple of doublets within 6.8-7 ppm ascribable to the $\mathrm{N}-\mathrm{CH}_{2}-\mathrm{N}$ and to the imidazole protons together with the aromatic signals within 7.2 and $8 \mathrm{ppm}$ are identified in the ${ }^{1} \mathrm{H}$ NMR spectrum. The ${ }^{13} \mathrm{C}$ NMR spectrum of $4 \mathbf{c}$ displays the resonances of carbene and carbonyl carbons at ca. 182 and 178 ppm, respectively. The benzyl, the olefin and the carbons of the spacer resonate at ca. 53, 63 and 62 ppm, respectively (See Supplementary Material Fig. S3a-c and Section 5).

\section{4. (E)-1,2-bis(p-tolylsulfonyl)ethene complexes $4 \boldsymbol{d}$ and $\mathbf{5 d}$}

(E)-1,2-bis(p-tolylsulfonyl)ethene (trans-sulf) was obtained following published procedures [16] and is the most stabilizing olefin among those used in this work. As a matter of fact complexes $4 \mathbf{d}$ or 5d were promptly obtained on following the usual protocol of Scheme 3 starting from complex 1d and the silver derivatives 2 or 3 . However, the synthesis of the analogous complexes bearing the olefin (Z)-1,2-bis(p-tolylsulfonyl)ethene (cis-sulf) $\mathbf{4} \mathbf{d}^{\prime}$ and $\mathbf{5} \mathbf{d}^{\prime}$ starting from $\mathbf{1} \mathbf{d}^{\prime}$, failed. Independently of the starting complexes 1d or $\mathbf{1} \mathbf{d}^{\prime}$ we obtained in any case complexes $4 \mathbf{d}$ and $\mathbf{5 d}$ bearing the trans-sulf as stabilizing olefin (See Scheme 4).

The isolated complexes are stable and were characterized by NMR and IR techniques (See Supplementary Material Fig. S5a-d and Section 5). Thus, in the ${ }^{1} \mathrm{H}$ NMR spectra of both the complexes it is possible to observe a singlet $\left(\mathrm{CH}_{3}\right.$ protons of the tolyl groups of the olefin) at $2.4 \mathrm{ppm}$, a singlet at ca. 3.7-3.8 ppm (olefinic protons), a singlet at $5.8 \mathrm{ppm}$ (spacer of $\mathbf{4 d}$ ), an $A B$ system within 4.6-5 ppm (spacer of 5d) and eventually an $A B$ system within 5.3-5.8 ppm ( $\mathrm{CH}_{2}$ protons of the benzyl substituents). The ${ }^{13} \mathrm{C}$

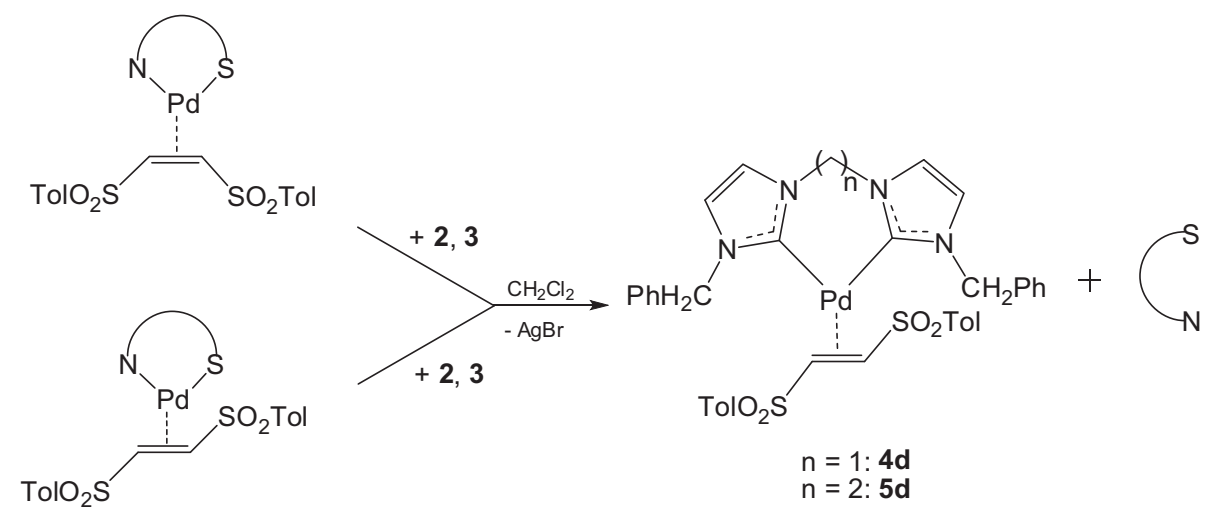

Scheme 4. Reaction of complexes $\mathbf{1 d}$ or $\mathbf{1} \mathbf{d}^{\prime}$ with $\mathbf{2}$ and $\mathbf{3}$ yielding complexes $\mathbf{4 d}$ and $\mathbf{5 d}$ only. 
NMR spectra are characterized by a signal at ca. 21-22 ppm $\left(\mathrm{CH}_{3}-\mathrm{Tol}\right)$, a couple of peaks at 55 and $56 \mathrm{ppm}$ (olefin carbons and benzyl $\mathrm{CH}_{2}$, respectively), the spacer carbons at $63\left(\mathrm{NCH}_{2} \mathrm{~N}\right)$ and $48.7 \mathrm{ppm}\left(\mathrm{NCH}_{2} \mathrm{CH}_{2} \mathrm{~N}\right)$ and finally the coordinated carbene carbon at ca. $186 \mathrm{ppm}$.

The solid-state structure of complex $\mathbf{4 d}$ was determined and its ORTEP representation [17] is reported in Fig. 1 whereas the discussion will be dealt later.

The isomerization of the coordinated olefins to the $\operatorname{Pd}(0)$ center, although not unprecedented, was faster in this case with the biscarbene as spectator ligand than that we have previously observed

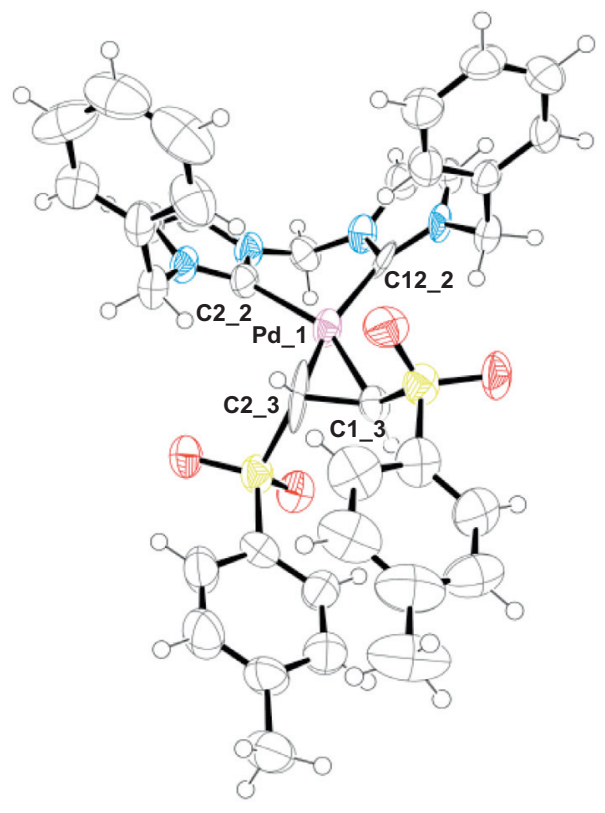

Fig. 1. Ellipsoid representation of $\mathbf{4 d}$ crystal ASU contents (50\% probability). Atom labels in use for Pd coordination sphere are reported.

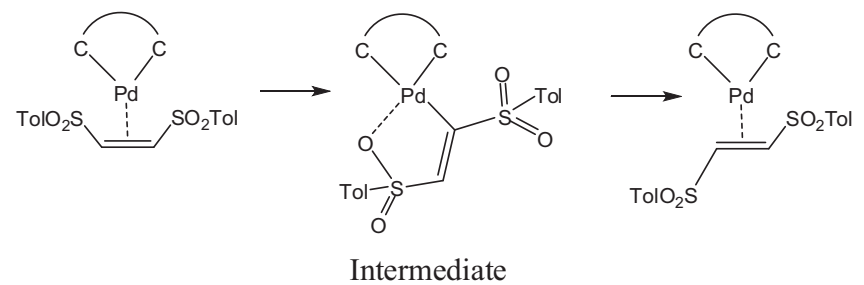

Scheme 5. Proposed intermediate involved in the isomerization of the coordinated cis-sulf. when the ancillary ligands were chelating phosphoquinolines [12]. As a matter of fact, at variance with the reaction rate which was hitherto measureable by NMR technique, in the present case the rate of formation of complex $\mathbf{4 d}$ (or $\mathbf{5 d}$ ) starting from $\mathbf{1 d}^{\prime}$ was not measured, the olefin isomerization being almost immediate (few minutes). Thus, the NMR spectra can only reveal the appearance of the final species 4d (or 5d). Apparently, the strong $\sigma$ donating character of the Fischer bis-carbene promotes the olefin isomerisation much more efficiently than phosphine ligands.

In particular, according to the mechanism proposed [12] we surmise that the enhanced electronic density on palladium promoted by the bis-carbene favors the formation of the intermediate reported in Scheme 5.

\subsection{Tetramethyl ethene-1,1,2,2-tetracarboxhylate complex $\mathbf{4 e}$}

The occurrence of the trans-metalation between 1e and complexes 2, 3 was observed in both cases by ${ }^{1} \mathrm{H}$ NMR spectroscopy, but only complex $\mathbf{4 e}$ was stable enough to be isolated and characterized.

In order to minimize the decomposition of complex $\mathbf{4 e}$, the trans-metalation was carried out at $223 \mathrm{~K}$ and the ensuing complex isolated by customary methods (See Section 5). The ${ }^{1} \mathrm{H}$ NMR spectrum of complex $4 \mathbf{e}$ displays the singlet at $3.5 \mathrm{ppm}\left(\mathrm{OCH}_{3}\right.$ groups) and those at 5.6 and $5.8 \mathrm{ppm}$ were assigned to $\mathrm{CH}_{2} \mathrm{Ph}$ and $\mathrm{NCH}_{2} \mathrm{~N}$ protons, respectively (Fig. S6a Supplementary Material). The ${ }^{13} \mathrm{C}$ NMR spectrum displays the carbenic and carbonyl signals at 188 and 168 ppm, whereas the carbons of the $\mathrm{OCH}_{3}, \mathrm{CH}_{2} \mathrm{Ph}$ and $\mathrm{NCH}_{2} \mathrm{~N}$ resonate at 51, 54 and 64 ppm, respectively (Fig. S6b Supplementary Material).

A quite intriguing peculiarity related to complex $\mathbf{4 e}$ emerged as a consequence of its $24 \mathrm{~h}$ decomposition in $\mathrm{CD}_{2} \mathrm{Cl}_{2}$ or $\mathrm{CDCl}_{3}$ solution. Beside the solid products of decomposition a novel species characterized by a very simple ${ }^{1} \mathrm{H}$ NMR spectrum was detected in the filtered solution (Fig. 2).

In order to understand the nature of the species we have performed the mass spectrometry of the compound which was identified as tetramethyl ethane-1,1,2,2-tetracarboxylate $\left(D_{2}\right)$. As a matter of fact similar species were proposed by Spencer and coworkers in the case of palladium catalyzed reduction of cis-olefins [18] but we cannot exclude a mechanism involving radicals for the decomposition process. Eventually, we have carried out the decomposition in $\mathrm{CH}_{2} \mathrm{Cl}_{2}$ and as can be seen in the mass spectrum of Fig. 3, we obtained the undeuterated analog tetramethyl ethane1,1,2,2-tetracarboxylate.

\subsection{Dimethylfumarate complexes $\mathbf{4} \boldsymbol{f}$ and $\mathbf{5 f}$}

Since it is not possible to prepare the pure dimethylfumarate derivative of the 2-methyl-6-(phenylthiomethyl)pyridine ligand, complexes $\mathbf{4 f}$ and $\mathbf{5 f}$ were synthesized starting from complex $\mathbf{1 f}$
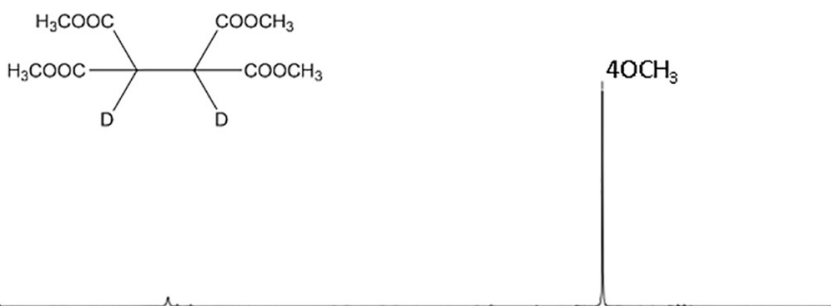

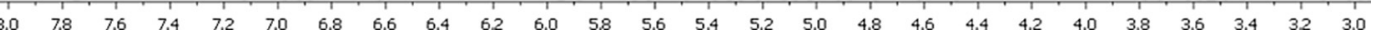

Fig. 2. ${ }^{1} \mathrm{H}$ NMR spectrum of the solution obtained by filtration of the by-products of the decomposition of complex $\mathbf{4 e}$ in $\mathrm{CDCl}_{3}$. 


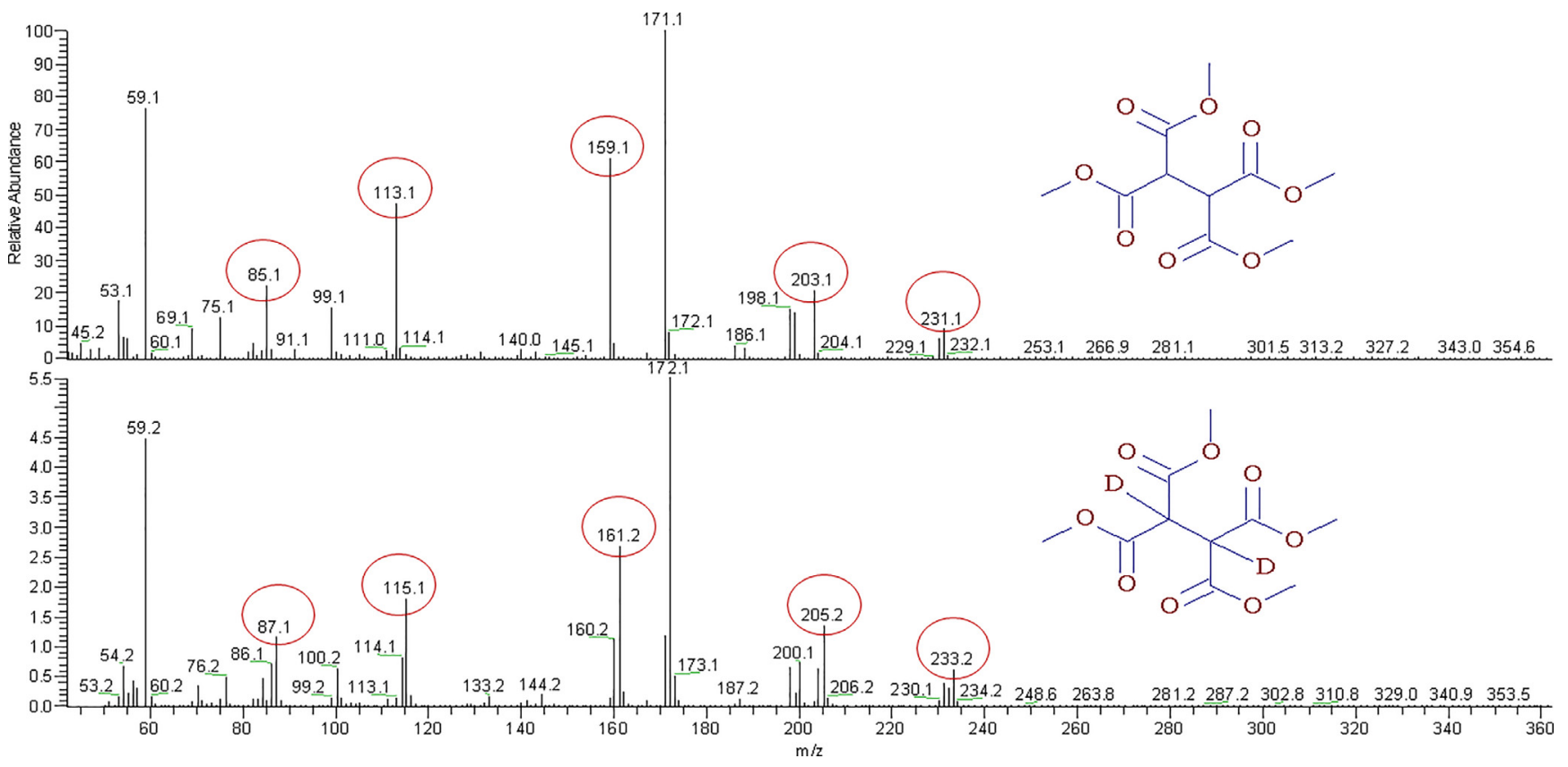

Fig. 3. Mass spectra of tetramethyl ethane-1,1,2,2-tetracarboxylate (top) and tetramethyl ethane-1,1,2,2-tetracarboxylate ( $\left.D_{2}\right)$ (bottom).

which is stabilized by the spectator ligand 2-methyl-8(methylthio)quinoline (See Scheme 2). It was already stated that complexes characterized by the concomitant coordination of a strong $\sigma$-donor carbene (two in this case) need a strongly deactivated olefin to be stabilized. Yet, dimethylfumarate (dmfu), among the investigated olefins, is the less performing one. However, we were able to synthesize (at $233 \mathrm{~K}$ ), isolate and characterize by usual spectral techniques the complexes $\mathbf{4 f}$ and $\mathbf{5 f}$. Thus, (see Fig. S7a-d, Supplementary Material) the ${ }^{1} \mathrm{H}$ NMR spectra of both derivatives display two singlets at ca. 3.3 and $3.6 \mathrm{ppm}$ ascribable to $\mathrm{OCH}_{3}$ and olefin protons, respectively. Another singlet at 5.3 (or 5.9) ppm related to the proton of the spacers $\mathrm{NCH}_{2} \mathrm{~N}$ (or $\left.\mathrm{NCH}_{2} \mathrm{CH}_{2} \mathrm{~N}\right)$, an $\mathrm{AB}$ system within $4.6-5.6 \mathrm{ppm}\left(\mathrm{CH}_{2} \mathrm{Ph}\right)$ and a doublet within 6.8-7.2 ppm (imidazole protons) are found in the proton spectra. In the ${ }^{13} \mathrm{C}$ NMR spectra the signals at 38 (olefin carbons), $51\left(\mathrm{OCH}_{3}\right), 53\left(\mathrm{CH}_{2} \mathrm{Ph}\right)$ and within $55-53 \mathrm{ppm}\left(\mathrm{NCH}_{2} \mathrm{~N}\right.$ and $\mathrm{NCH}_{2} \mathrm{CH}_{2} \mathrm{~N}$ spacers, respectively) are detected. The complete assignment of the signals is given by those at ca. $178 \mathrm{ppm}$ (CO) and at ca. $187 \mathrm{ppm}$ (coordinated carbene carbon).

\section{X-ray diffraction analysis}

\subsection{Structural characterization of complex $\mathbf{4 d}$}

The crystalline form of $\mathbf{4 d}$ contains one crystallographically independent palladium complex (Figs. 1 and S8a-b in Supplementary Material). A query on CSD (version 5.39), using the OlefinPd-1,1'-dibenzyl-3,3'methylenediimidazol-2,2'-diylidene fragment

Table 1

Selected bond distances and angles ( $\AA$ and ${ }^{\circ}$ ) for 4d palladium coordination sphere. Naming scheme is reported in Fig. 1.

\begin{tabular}{llll}
\hline 4d & & & \\
\hline Distances & $(\AA)$ & Angles & $\left(^{\circ}\right)$ \\
\hline Pd_1-C2_2 & $1.954(19)$ & C2_2-Pd_1-C2_3 & $110.05(54)$ \\
Pd_1-C12_2 & $2.065(14)$ & C2_3-Pd_1-C1_3 & $42.31(50)$ \\
Pd_1-C1_3 & $2.098(13)$ & C1_3-Pd_1-C12_2 & $121.41(47)$ \\
Pd_1-C2_3 & $2.065(12)$ & C12_2-Pd_1-C2_2 & $86.36(49)$ \\
\hline
\end{tabular}

gives, as a result, the structure of a similar $\operatorname{Pd}(0)$ complex bound to an imidazolylidene ligand and maleic anhydride (CCDC 908658) [9a]. The palladium(0) centre in this complex adopts a square planar coordination sphere, equivalent to $\mathbf{4 d}$, with similar bond lengths and angles (Tables 1 and S1; Supplementary Material). Table S1 shows that the low oxidation state leads to significantly longer bond lengths compared to similar $\mathrm{Pd}(\mathrm{II})$ complexes [19] (or $\mathrm{Rh}(\mathrm{III})$ [20]), bearing the same imidazolylidene ligand used in this work.

The 1,1'-dibenzyl-3,3'methylenediimidazol-2,2'-diylidene scaffold is rather flexible as shown by the angle between the imidazole average planes. Similar values have been found among $\mathbf{A}$ and the two square planar Pd(II) complexes reported in Table S1 (see line "Imidazole Ave. Planes") but they are significantly reduced (33.77 $(12)^{\circ}$ ) in the Rh complex[C] (CCDC number 633257) which bears the same ligand reported in this work, in a bulkier octahedral coordination sphere (Fig. S9a; Supplementary Material).

The $\mathrm{C}=\mathrm{C}$ double bond of the olefin, which is $\eta^{2}$ coordinated to the metal center and almost perpendicular to the coordination plane, is lenghtened compared to the free alkene due to $\pi$-back bonding from the Palladium(0).

Crystal packing of $\mathbf{4 d}$ shows hydrophobic contacts among neighbor molecules, involving $\mathrm{CH} \cdots \pi$ and $\pi \cdots \pi$ interactions. Furthermore, 4d structure shows intramolecular stacking between the tosyl groups of the coordinated olefin (Fig. S9b: Supplementary Material - angle between phenyl mean planes is $1.83(1)^{\circ}$, with average distance between planes of 3.66(1) Å and $1.36 \AA$ ring centroids slippage).

\section{Conclusion}

We have synthesized ten new $\operatorname{Pd}(0)$ complexes with six different deactivated olefins bearing bulky bis-carbenes as spectator ligands. Thanks to our synthetic protocol based on the trans-metalation reaction between silver carbene and $\mathrm{Pd}(0)$ olefin pyridylthioether (or quinolylthioether) complexes we have isolated quite elusive species otherwise not easily achievable. The isolated species stabilized by maleic anhydride, fumaronitrile and 1,2-bis(ptolylsulfonyl)ethene were stable in the solid and in solution. The 
derivatives of dimethylfumarate and naphthoquinone decompose in solution giving undefined products, whereas the tetramethylethylenetetracarboxylate complexes decompose yielding unexpectedly the tetramethylethane-1,1,2,2-tetracarboxylate $\left(D_{2}\right)$. Generally speaking, the synthesized species fits in the stability trend imparted by olefins we established so far [10]. Moreover, the presence of the bis-carbene ligand promotes a faster isomerization of the olefin (Z)-1,2-bis(p-tolylsulfonyl)ethene (cis-sulf) into (E)-1,2-bis(tolylsulfonyl)ethene (trans-sulf) than that previously observed [12]. Finally one of the few available solid-state structures of this kind of derivatives was resolved.

\section{Experimental}

\subsection{Solvents and reagents}

The solvent $\mathrm{CH}_{2} \mathrm{Cl}_{2}$ and $\mathrm{CHCl}_{3}$ were distilled over $\mathrm{CaH}_{2}$, acetone was refluxed over $4 \AA$ A molecular sieves and distilled. All other solvents and chemicals were commercial grade products and used as purchased.

\subsection{IR, NMR, UV-Vis measurements and elemental analysis}

The IR, ${ }^{1} \mathrm{H},{ }^{13} \mathrm{C}$ and ${ }^{31} \mathrm{P}$ NMR spectra were recorded on a PerkinElmer Spectrum One spectrophotometer and on a Bruker 300 Avance spectrometer, respectively. The elemental analysis of the synthesized complexes was carried out using an Elementar CHN "CUBO micro Vario" analyzer.

\subsection{Crystal structure determination}

The crystal data of $4 \mathbf{d}$ were collected at $100 \mathrm{~K}$ at the XRD1 beamline of the Elettra Synchrotron, Trieste (Italy) [21], using a monochromatic wavelength of $0.700 \AA$. The data sets were integrated and corrected for Lorentz and polarization effects with the XDS package [22]. Semi-empirical absorption corrections and scaling were performed on datasets, exploiting multiple measurements of symmetry-related reflections, using SADABS program [23]. Crystals of 4d showed significant radiation damage upon exposure to X-rays, therefore data from two different crystals were merged to obtain a complete set of data. The structures were solved by direct methods using sHeLXT program [24] and refined using fullmatrix least-squares with all non-hydrogen atoms anisotropically and hydrogens included on calculated positions, riding on their carrier atoms. Thermal restraints (SIMU) were applied to the palladium coordination sphere (mainly on the olefin moiety): spurious electron density peaks have been found close to the metal centre, as a radiation damage consequence. Disordered solvent contributions (corresponding to $\sim 1 / 3$ of a $\mathrm{CH}_{2} \mathrm{Cl}_{2}$ molecule, in the cell), were removed with Platon SQUEEZE [25] routine $\left(14 \mathrm{e}^{-} /\right.$cell squeezed, in $143 \AA^{3}$ volume voids/cell). Model refinement was performed using SHELXL-2018/1 [26]. The Coot program was used for structure building [27]. The crystal data are given in Table S2 (Supplementary Material). Pictures were prepared using ORTEP3 [17] and PYMOL [28] softwares. Crystallographic data have been deposited at the Cambridge Crystallographic Data Centre and allocated the deposition number CCDC 1844914. These data can be obtained free of charge via https://www.ccdc.cam.ac.uk/structures.

\subsection{Synthesis of the silver complexes $\mathbf{2}$ and $\mathbf{3}$}

To $269.3 \mathrm{mg} / 0.543 \mathrm{mmol}$ of the imidazolium salt $1,1^{\prime}$-dibenzyl$3,3^{\prime}$ methylenediimidazolium di bromide ([BnImCH $\left.\mathrm{H}_{2} \mathrm{ImBn}\right] \mathrm{H}_{2} \mathrm{Br}_{2}$ ) dissolved in $35 \mathrm{~mL}$ of anhydrous methanol in a two neck $100 \mathrm{~mL}$ flask, under inert atmosphere (Ar) $165.5 \mathrm{mg}(0.714 \mathrm{mmol})$ of
$\mathrm{Ag}_{2} \mathrm{O}$, were added. The resulting mixture was stirred in the dark for $2 \mathrm{~h}$ and then filtered off on a millipore apparatus. The clear solution was dried under vacuum, dissolved in the minimum volume of $\mathrm{CH}_{2} \mathrm{Cl}_{2}$ and the title complex precipitated by addition of diethylether as a pink solid. The product was filtered off in a gooch and dried under vacuum. $244.5 \mathrm{mg}$ (yield 63\%) of the derivative 2 were obtained.

${ }^{1} \mathrm{H}$ NMR (300 MHz, d $\mathrm{d}_{6}$-DMSO, $\left.T=298 \mathrm{~K}, \mathrm{ppm}\right) \delta: 5.18(\mathrm{~s}, 4 \mathrm{H}$, $\left.2 \mathrm{CH}_{2} \mathrm{Ph}\right), 7.05\left(\mathrm{~s}, 2 \mathrm{H}, 2 \mathrm{CH}^{\mathrm{Im}}\right), 7.04-7.23(\mathrm{~m}, 10 \mathrm{H}, 2 \mathrm{Ph}), 7.54(\mathrm{~s}$, $\left.2 \mathrm{H}, 2 \mathrm{CH}^{\mathrm{Im}}\right), 7.93\left(\mathrm{~s}, 2 \mathrm{H}, \mathrm{NCH}_{2} \mathrm{~N}\right)$.

${ }^{13} \mathrm{C}\left\{{ }^{1} \mathrm{H}\right\}$ NMR $\left(\mathrm{d}_{6}\right.$-DMSO, $\left.\mathrm{T}=298 \mathrm{~K}, \mathrm{ppm}\right) \delta: 54.9\left(\mathrm{CH}_{2}, \mathrm{CH}_{2} \mathrm{Ph}\right)$, $63.4\left(\mathrm{CH}_{2}, \mathrm{NCH}_{2} \mathrm{~N}\right), 123.0\left(\mathrm{CH}, \mathrm{CH}^{\mathrm{Im}}\right), 123.5\left(\mathrm{CH}, \mathrm{CH}^{\mathrm{Im}}\right), 127.5-$ $137.1(\mathrm{Ph}), 182.6$ (C, carbene).

Anal. Calc. for $\mathrm{C}_{21} \mathrm{H}_{20} \mathrm{Ag}_{2} \mathrm{Br}_{2} \mathrm{~N}_{4}$ : C, 35.83; $\mathrm{H}, 2.86 ; \mathrm{N}, 7.96$. Found: C, 35.71; H, 2.93; N, 7.89\%.

The silver complex $\mathbf{3}$ was obtained following the same synthetic scheme of complex 2 by reacting $252 \mathrm{mg}(0.500 \mathrm{mmol})$ of the imidazolium salt 1,1'-dibenzyl-3,3'ethylenediimidazolium dibromide.

([BnImCH $\left.\mathrm{CH}_{2} \mathrm{ImBn}\right] \mathrm{H}_{2} \mathrm{Br}_{2}$ with $150 \mathrm{mg}$ (0.650 mmol) of $\mathrm{Ag}_{2} \mathrm{O}$. $212.3 \mathrm{mg}$ of the pink solid 3 were obtained (yield 59\%).

${ }^{1} \mathrm{H}$ NMR (300 MHz, d 6 -DMSO, $\left.T=298 \mathrm{~K}, \mathrm{ppm}\right) \delta: 4.65(\mathrm{~s}, 4 \mathrm{H}$, $\left.\mathrm{NCH}_{2} \mathrm{CH}_{2} \mathrm{~N}\right), 5.17\left(\mathrm{~s}, 4 \mathrm{H}, 2 \mathrm{CH}_{2} \mathrm{Ph}\right), 6.98-7.26(\mathrm{~m}, 10 \mathrm{H}, 2 \mathrm{Ph}), 7.45$ (d, $\left.2 \mathrm{H}, J=1.8 \mathrm{~Hz}, 2 \mathrm{CH}^{\mathrm{Im}}\right), 7.48\left(\mathrm{~d}, 2 \mathrm{H}, J=1.8 \mathrm{~Hz}, 2 \mathrm{CH}^{\mathrm{Im}}\right)$.

${ }^{13} \mathrm{C}\left\{{ }^{1} \mathrm{H}\right\}$ NMR $\left(\mathrm{d}_{6}\right.$-DMSO, $\left.T=298 \mathrm{~K}, \mathrm{ppm}\right) \delta$ : $51.5\left(\mathrm{CH}_{2}\right.$, $\left.\mathrm{NCH}_{2} \mathrm{CH}_{2} \mathrm{~N}\right), 54.5\left(\mathrm{CH}_{2}, \mathrm{CH}_{2} \mathrm{Ph}\right), 122.9\left(\mathrm{CH}, \mathrm{CH}^{\mathrm{Im}}\right), 123.3\left(\mathrm{CH}, \mathrm{CH}^{\mathrm{Im}}\right)$, 127.4-137.5 (Ph), 180.8 (C, carbene).

Anal. Calcd. for $\mathrm{C}_{22} \mathrm{H}_{22} \mathrm{Ag}_{2} \mathrm{Br}_{2} \mathrm{~N}_{4}: \mathrm{C}, 36.80 ; \mathrm{H}, 3.09 ; \mathrm{N}, 7.80$. Found: C, 36.84; H, 3.03; N, 7.77\%.

\section{Synthesis of type 4 complexes}

\subsection{Synthesis of the ma complex $\mathbf{4 a}$}

To $45.8 \mathrm{mg}(0.110 \mathrm{mmol})$ of complex 1a dissolved in $20 \mathrm{~mL}$ of anhydrous $\mathrm{CH}_{2} \mathrm{Cl}_{2}$ in a two neck $50 \mathrm{~mL}$ flask under inert atmosphere $(\mathrm{Ar}) 76.8 \mathrm{mg}(0.110 \mathrm{mmol})$ of the silver complex 2 , were added. The resulting brown mixture was stirred for $20 \mathrm{~min}$ and then filtered on a millipore apparatus and the clear solution concentrated under vacuum. The addition of diethylether induces the precipitation of complex $\mathbf{4 a}$ which was filtered off in a gooch and dried under vacuum. $55.4 \mathrm{mg}$ (yield 95\%) of the title compound were obtained as a brown solid.

${ }^{1} \mathrm{H}$ NMR $\left(\mathrm{CDCl}_{3}, T=298 \mathrm{~K}, \mathrm{ppm}\right) \delta: 2.88\left(\mathrm{~s}, 3 \mathrm{H}, \mathrm{CH}_{3}\right), 4.23(\mathrm{~s}, 2 \mathrm{H}$, $\mathrm{CH}=\mathrm{CH}), 4.49\left(\mathrm{~s}, 2 \mathrm{H}, \mathrm{SCH}_{2}\right), 7.21(\mathrm{~d}, 1 \mathrm{H}, J=7.7 \mathrm{~Hz}, 5-\mathrm{pyr}), 7.31-$ $7.36(\mathrm{~m}, 4 \mathrm{H}, 3-\mathrm{pyr}, \mathrm{Ph}), 7.52-7.65(\mathrm{~m}, 2 \mathrm{H}, \mathrm{Ph}), 7.66(\mathrm{t}, 1 \mathrm{H}$, $J=7.7 \mathrm{~Hz}, 4-\mathrm{pyr})$.

Anal. Calc. for $\mathrm{C}_{25} \mathrm{H}_{22} \mathrm{~N}_{4} \mathrm{O}_{3} \mathrm{Pd}$ : C, 56.35; $\mathrm{H}, 4.16 ; \mathrm{N}, 10.51$. Found: C, $56.46 ; \mathrm{H}, 4.21 ; \mathrm{N}, 10.63 \%$.

IR (KBr): $v_{\mathrm{C}=\mathrm{O}}=1723,1793 \mathrm{~cm}^{-1}$.

Derivatives $\mathbf{4 b}$ and $\mathbf{4 d}, \mathbf{5 a}-\mathbf{b}, \mathbf{5 d}$ and $\mathbf{5 f}$ were prepared in a similar way using the appropriate reactants.

The color of the complexes, the reaction time and the yield are reported at the top of each characterization.

\subsection{Synthesis of the ma complex $\mathbf{5 a}$}

Brown microcrystals, 20 min, yield $99 \%$.

${ }^{1} \mathrm{H}$ NMR $\left(300 \mathrm{MHz}, \mathrm{CD}_{2} \mathrm{Cl}_{2}, T=298 \mathrm{~K}, \mathrm{ppm}\right) \delta: 3.62(\mathrm{~s}, 2 \mathrm{H}$, $\left.2 \mathrm{CH}^{\mathrm{ma}}\right), 4.63-4.78\left(\mathrm{~m}, 4 \mathrm{H}, \mathrm{NCH}_{2} \mathrm{CH}_{2} \mathrm{~N}\right), 5.20-5.34$ (AB system, $4 \mathrm{H}$, $\left.J=14.8 \mathrm{~Hz}, 2 \mathrm{CH}_{2} \mathrm{Ph}\right), 6.89$ (d, $\left.2 \mathrm{H}, J=1.9 \mathrm{~Hz}, 2 \mathrm{CH}^{\mathrm{Im}}\right), 6.97$ (d, $2 \mathrm{H}$, $\left.J=1.9 \mathrm{~Hz}, 2 \mathrm{CH}^{\mathrm{Im}}\right), 7.30-7.35(\mathrm{~m}, 10 \mathrm{H}, 2 \mathrm{Ph})$.

${ }^{13} \mathrm{C}\left\{{ }^{1} \mathrm{H}\right\}$ NMR $\left(\mathrm{CDCl}_{3}, T=243 \mathrm{~K}, \mathrm{ppm}\right) \delta: 38.7\left(\mathrm{CH}, \mathrm{CH}^{\mathrm{ma}}\right), 48.6$ $\left(\mathrm{CH}_{2}, \mathrm{NCH}_{2} \mathrm{CH}_{2} \mathrm{~N}\right), 55.3\left(\mathrm{CH}_{2}, \mathrm{CH}_{2} \mathrm{Ph}\right), 120.8\left(\mathrm{CH}, \mathrm{CH}^{\mathrm{Im}}\right), 122.2(\mathrm{CH}$, $\left.\mathrm{CH}^{\mathrm{Im}}\right), 128.3-136.6(\mathrm{Ph}), 175.7(\mathrm{C}, \mathrm{C}=\mathrm{O}), 184.1$ (C, carbene). 
Anal. Calc. for $\mathrm{C}_{26} \mathrm{H}_{24} \mathrm{~N}_{4} \mathrm{O}_{3} \mathrm{Pd}$ : C, 57.10; $\mathrm{H}, 4.42 ; \mathrm{N}, 10.24$. Found:

C, $57.21 ; \mathrm{H}, 4.33 ; \mathrm{N}, 10.18 \%$.

IR $(\mathrm{KBr}): v_{\mathrm{C}=\mathrm{O}}=1750,1704,1683, v_{\mathrm{C}-\mathrm{O}}=1232 \mathrm{~cm}^{-1}$.

\subsection{Synthesis of the fn complex $\mathbf{4 b}$}

Brown microcrystals, 30 min, yield $97 \%$.

${ }^{1} \mathrm{H}$ NMR (300 MHz, $\left.\mathrm{CD}_{2} \mathrm{Cl}_{2}, T=298 \mathrm{~K}, \mathrm{ppm}\right) \delta: 2.52(\mathrm{~s}, 2 \mathrm{H}$, $2 \mathrm{CH}^{\mathrm{fn}}$ ), 5.47-5.58 (AB system, $4 \mathrm{H}, J=14.7 \mathrm{~Hz}, 2 \mathrm{CH}_{2} \mathrm{Ph}$ ), 5.98 (s, $\left.2 \mathrm{H}, \mathrm{NCH}_{2} \mathrm{~N}\right), 6.98\left(\mathrm{~d}, 2 \mathrm{H}, J=1.9 \mathrm{~Hz}, 2 \mathrm{CH}^{\mathrm{Im}}\right), 7.18(\mathrm{~d}, 2 \mathrm{H}, J=1.9 \mathrm{~Hz}$, $\left.2 \mathrm{CH}^{\mathrm{Im}}\right), 7.37-7.41(\mathrm{~m}, 10 \mathrm{H}, 2 \mathrm{Ph})$.

${ }^{13} \mathrm{C}\left\{{ }^{1} \mathrm{H}\right\}$ NMR $\left(\mathrm{CDCl}_{3}, T=243 \mathrm{~K}, \mathrm{ppm}\right) \delta: 13.3\left(\mathrm{CH}, \mathrm{CH}^{\mathrm{fn}}\right), 55.4$ $\left(\mathrm{CH}_{2}, \mathrm{CH}_{2} \mathrm{Ph}\right), 63.2\left(\mathrm{CH}_{2}, \mathrm{NCH}_{2} \mathrm{~N}\right), 119.8\left(\mathrm{CH}, \mathrm{CH}^{\mathrm{Im}}\right), 121.3(\mathrm{CH}$, $\left.\mathrm{CH}^{\mathrm{Im}}\right), 127.3(\mathrm{C}, \mathrm{CN}), 128.2-136.2(\mathrm{Ph}), 185.7$ (C, carbene).

Anal. Calc. for $\mathrm{C}_{25} \mathrm{H}_{22} \mathrm{~N}_{6} \mathrm{Pd}$ : C, 58.54; H, 4.32; N, 16.39. Found: C, 58.67; H, 4.19; N, $16.48 \%$.

IR $(\mathrm{KBr}): v_{\mathrm{CN}}=2184 \mathrm{~cm}^{-1}$.

\subsection{Synthesis of the fn complex $\mathbf{5 b}$}

Brown microcrystals, 30 min, yield $91 \%$.

${ }^{1} \mathrm{H}$ NMR (300 MHz, $\left.\mathrm{CD}_{2} \mathrm{Cl}_{2}, T=298 \mathrm{~K}, \mathrm{ppm}\right) \delta: 2.34(\mathrm{~s}, 2 \mathrm{H}$, $2 \mathrm{CH}^{\text {fn }}$ ), 4.63-4.90 (AB system, $4 \mathrm{H}, J=11.3 \mathrm{~Hz}, \mathrm{NCH}_{2} \mathrm{CH}_{2} \mathrm{~N}$ ), 5.265.50 (AB system, $4 \mathrm{H}, J=14.8 \mathrm{~Hz}, 2 \mathrm{CH}_{2} \mathrm{Ph}$ ), $6.93(\mathrm{~d}, 2 \mathrm{H}, J=1.9 \mathrm{~Hz}$, $\left.2 \mathrm{CH}^{\mathrm{Im}}\right), 6.99\left(\mathrm{~d}, 2 \mathrm{H}, J=1.9 \mathrm{~Hz}, 2 \mathrm{CH}^{\mathrm{Im}}\right), 7.32-7.34(\mathrm{~m}, 10 \mathrm{H}, 2 \mathrm{Ph})$

${ }^{13} \mathrm{C}\left\{{ }^{1} \mathrm{H}\right\}$ NMR $\left(\mathrm{CDCl}_{3}, T=243 \mathrm{~K}, \mathrm{ppm}\right) \delta: 12.6\left(\mathrm{CH}, \mathrm{CH}^{\mathrm{fn}}\right), 48.7$ $\left(\mathrm{CH}_{2}, \mathrm{NCH}_{2} \mathrm{CH}_{2} \mathrm{~N}\right), 55.2\left(\mathrm{CH}_{2}, \mathrm{CH}_{2} \mathrm{Ph}\right), 120.8\left(\mathrm{CH}, \mathrm{CH}^{\mathrm{Im}}\right), 121.9(\mathrm{CH}$, $\left.\mathrm{CH}^{\mathrm{Im}}\right), 127.5$ (C, CN), 128.0-136.8 (Ph), 186.1 (C, carbene).

Anal. Calc. for $\mathrm{C}_{26} \mathrm{H}_{24} \mathrm{~N}_{6} \mathrm{Pd}$ : C, 59.26; H, 4.59; N, 15.95. Found: $\mathrm{C}$, 59.32; H, 4.67; N, 15.82 .

IR $(\mathrm{KBr}): v_{\mathrm{CN}}=2184 \mathrm{~cm}^{-1}$.

\subsection{Synthesis of the trans-sulf complex $\mathbf{4 d}$}

Pink microcrystals, $30 \mathrm{~min}$, yield $98 \%$.

${ }^{1} \mathrm{H}$ NMR (300 MHz, $\left.\mathrm{CD}_{2} \mathrm{Cl}_{2}, T=298 \mathrm{~K}, \mathrm{ppm}\right) \delta: 2.37\left(\mathrm{~s}, 6 \mathrm{H}, 2 \mathrm{CH}_{3}\right.$ $\left.{ }^{\mathrm{Tol}}\right), \quad 3.81\left(\mathrm{~s}, 2 \mathrm{H}, 2 \mathrm{CH}^{\text {trans-disulf }}\right), \quad 5.68-5.82$ (AB system, $4 \mathrm{H}$, $\left.J=14.6 \mathrm{~Hz}, 2 \mathrm{CH}_{2} \mathrm{Ph}\right), 5.97\left(\mathrm{~s}, 2 \mathrm{H}, \mathrm{NCH}_{2} \mathrm{~N}\right), 6.95(\mathrm{~d}, 2 \mathrm{H}, J=1.9 \mathrm{~Hz}$, $\left.2 \mathrm{CH}^{\mathrm{Im}}\right), 7.17\left(\mathrm{~d}, 2 \mathrm{H}, J=1.9 \mathrm{~Hz}, 2 \mathrm{CH}^{\mathrm{Im}}\right), 6.91-7.55(\mathrm{~m}, 18 \mathrm{H}$, aryl-H).

${ }^{13} \mathrm{C}\left\{{ }^{1} \mathrm{H}\right\}$ NMR $\left(\mathrm{CDCl}_{3}, T=298 \mathrm{~K}, \mathrm{ppm}\right) \delta: 21.5\left(\mathrm{CH}_{3}, \mathrm{CH}_{3}^{\mathrm{Tol}}\right), 54.6$ $\left(\mathrm{CH}, \mathrm{CH}^{\text {trans-disulf }}\right), 55.9\left(\mathrm{CH}_{2}, \mathrm{CH}_{2} \mathrm{Ph}\right), 63.1\left(\mathrm{CH}_{2}, \mathrm{NCH}_{2} \mathrm{~N}\right), 119.6$ $\left(\mathrm{CH}, \mathrm{CH}^{\mathrm{Im}}\right), 120.8\left(\mathrm{CH}, \mathrm{CH}^{\mathrm{Im}}\right), 126.1-141.4(\mathrm{Ph}), 185.8$ (C, carbene). Anal. Calcd. for $\mathrm{C}_{37} \mathrm{H}_{36} \mathrm{~N}_{4} \mathrm{O}_{4} \mathrm{PdS}_{2}$ : C, 57.62; H, 4.70; N, 7.26. Found: C, 57.71; $\mathrm{H}, 4.83 ; \mathrm{N}, 7.19 \%$.

IR $(\mathrm{KBr}): v_{\mathrm{S}=\mathrm{O}}=1276,1126 \mathrm{~cm}^{-1}$.

\subsection{Synthesis of the trans-sulf complex $\mathbf{5 d}$}

Pink microcrystals, $30 \mathrm{~min}$, yield $97 \%$.

${ }^{1} \mathrm{H}$ NMR (300 MHz, $\left.\mathrm{CD}_{2} \mathrm{Cl}_{2}, T=298 \mathrm{~K}, \mathrm{ppm}\right) \delta: 2.37\left(\mathrm{~s}, 6 \mathrm{H}, 2 \mathrm{CH}_{3}\right.$ $\left.{ }^{\mathrm{Tol}}\right), \quad 3.66\left(\mathrm{~s}, 2 \mathrm{H}, 2 \mathrm{CH}^{\text {trans-disulf }}\right), 4.57-5.01$ (AB system, 4H, $J=11.3 \mathrm{~Hz}, \mathrm{NCH}_{2} \mathrm{CH}_{2} \mathrm{~N}$ ), $5.36-5.63$ (AB system, $4 \mathrm{H}, J=14.6 \mathrm{~Hz}$, $\left.2 \mathrm{CH}_{2} \mathrm{Ph}\right), 6.88\left(\mathrm{~d}, 2 \mathrm{H}, J=1.9 \mathrm{~Hz}, 2 \mathrm{CH}^{\mathrm{Im}}\right), 6.98(\mathrm{~d}, 2 \mathrm{H}, J=1.9 \mathrm{~Hz}$, $\left.2 \mathrm{CH}^{\mathrm{Im}}\right), 6.92-7.47(\mathrm{~m}, 18 \mathrm{H}$, aryl-H).

${ }^{13} \mathrm{C}\left\{{ }^{1} \mathrm{H}\right\}$ NMR $\left(\mathrm{CDCl}_{3}, T=298 \mathrm{~K}, \mathrm{ppm}\right) \delta: 21.5\left(\mathrm{CH}_{3}, \mathrm{CH}_{3}^{\mathrm{Tol}}\right), 48.7$ $\left(\mathrm{CH}_{2}, \mathrm{NCH}_{2} \mathrm{CH}_{2} \mathrm{~N}\right), 54.0\left(\mathrm{CH}, \mathrm{CH}^{\text {trans-disulf }}\right), 55.9\left(\mathrm{CH}_{2}, \mathrm{CH}_{2} \mathrm{Ph}\right), 120.5$ $\left(\mathrm{CH}, \mathrm{CH}^{\mathrm{Im}}\right), 121.2\left(\mathrm{CH}, \mathrm{CH}^{\mathrm{Im}}\right), 126.1-141.6(\mathrm{Ph}), 186.1$ (C, carbene).

Anal. Calc. for $\mathrm{C}_{38} \mathrm{H}_{38} \mathrm{~N}_{4} \mathrm{O}_{4} \mathrm{PdS}_{2}$ : C, 58.12; $\mathrm{H}, 4.88 ; \mathrm{N}, 7.13$. Found: C, 58.01; H, 4.97; N, 7.01\%.

IR (KBr): $v_{\mathrm{S}=\mathrm{O}}=1278,1135 \mathrm{~cm}^{-1}$.

\subsection{Synthesis of the dmfu complex $\mathbf{5 f}$}

Brown microcrystals, 60 min, yield $83 \%$.

${ }^{1} \mathrm{H}$ NMR (300 MHz, $\left.\mathrm{CD}_{2} \mathrm{Cl}_{2}, T=298 \mathrm{~K}, \mathrm{ppm}\right) \delta: 3.39(\mathrm{~s}, 6 \mathrm{H}$, $\left.2 \mathrm{OCH}_{3}\right), 3.43\left(\mathrm{~s}, 2 \mathrm{H}, 2 \mathrm{CH}^{\mathrm{dmfu}}\right), 4.54-4.85$ (AB system, $4 \mathrm{H}$,
$\left.J=11.6 \mathrm{~Hz}, \quad \mathrm{NCH}_{2} \mathrm{CH}_{2} \mathrm{~N}\right), 5.91\left(\mathrm{~s}, 4 \mathrm{H}, 2 \mathrm{CH}_{2} \mathrm{Ph}\right), 6.83(\mathrm{~d}, 2 \mathrm{H}$, $\left.J=2.0 \mathrm{~Hz}, 2 \mathrm{CH}^{\mathrm{Im}}\right), 6.91\left(\mathrm{~d}, 2 \mathrm{H}, J=2.0 \mathrm{~Hz}, 2 \mathrm{CH}^{\mathrm{Im}}\right), 7.29-7.39(\mathrm{~m}$, $10 \mathrm{H}, 2 \mathrm{Ph}$ ).

${ }^{13} \mathrm{C}\left\{{ }^{1} \mathrm{H}\right\}$ NMR $\left(\mathrm{CDCl}_{3}, T=243 \mathrm{~K}, \mathrm{ppm}\right) \delta: 38.4\left(\mathrm{CH}, \mathrm{CH}^{\mathrm{dmfu}}\right), 50.7$ $\left(\mathrm{CH}_{3}, \mathrm{OCH}_{3}\right), 52.9\left(\mathrm{CH}_{2}, \mathrm{NCH}_{2} \mathrm{CH}_{2} \mathrm{~N}\right), 55.2\left(\mathrm{CH}_{2}, \mathrm{CH}_{2} \mathrm{Ph}\right), 120.2(\mathrm{CH}$, $\left.\mathrm{CH}^{\mathrm{Im}}\right), 121.4\left(\mathrm{CH}, \mathrm{CH}^{\mathrm{Im}}\right), 128.1-137.0(\mathrm{Ph}), 177.6(\mathrm{C}, \mathrm{C}=\mathrm{O}), 187.0(\mathrm{C}$, carbene).

Anal. Calc. for $\mathrm{C}_{28} \mathrm{H}_{30} \mathrm{~N}_{4} \mathrm{O}_{4} \mathrm{Pd}$ : C, 56.71; H, 5.10; N, 9.45. Found: C, 56.87; H, 4.95; N, 9.29\%.

IR $(\mathrm{KBr}): v_{\mathrm{C}=\mathrm{O}}=1660 \mathrm{~cm}^{-1}, v_{\mathrm{C}-\mathrm{O}}=1237 \mathrm{~cm}^{-1}$.

\subsection{Synthesis of the nq complex $\mathbf{4 c}$}

To $24.5 \mathrm{mg}(0.05 \mathrm{mmol})$ of complex 1a dissolved in $30 \mathrm{~mL}$ of anhydrous $\mathrm{CH}_{2} \mathrm{Cl}_{2}$ in a two neck $100 \mathrm{~mL}$ flask under inert atmosphere (Ar) at $223 \mathrm{~K}$ (ethanol/liquid $\left.\mathrm{N}_{2}\right) .32 .6 \mathrm{mg}(0.046 \mathrm{mmol})$ of the silver complex 2 were added. The resulting brown mixture was stirred for $1 \mathrm{~h}$ and then filtered on a millipore apparatus and the clear solution concentrated under vacuum. The addition of diethylether induces the precipitation of complex $\mathbf{4 c}$ which was filtered off in a gooch and dried under vacuum. $31.31 \mathrm{mg}$ (yield 97\%) of the title compound were obtained as a brown solid.

${ }^{1} \mathrm{H}$ NMR $\left(300 \mathrm{MHz}, \mathrm{CD}_{2} \mathrm{Cl}_{2}, T=298 \mathrm{~K}, \mathrm{ppm}\right) \delta: 4.77(\mathrm{~s}, 2 \mathrm{H}$, $\left.2 \mathrm{CH}^{\mathrm{nq}}\right), 5.28-5.66\left(\mathrm{AB}\right.$ system, $\left.4 \mathrm{H}, J=15.0 \mathrm{~Hz}, 2 \mathrm{CH}_{2} \mathrm{Ph}\right), 5.70(\mathrm{~s}$, $\left.2 \mathrm{H}, \mathrm{NCH}_{2} \mathrm{~N}\right), 6.88\left(\mathrm{~d}, 2 \mathrm{H}, J=1.9 \mathrm{~Hz}, 2 \mathrm{CH}^{\mathrm{Im}}\right), 7.07(\mathrm{~d}, 2 \mathrm{H}, J=1.9 \mathrm{~Hz}$, $\left.2 \mathrm{CH}^{\mathrm{Im}}\right), 7.25-7.93(\mathrm{~m}, 14 \mathrm{H}$, aryl-H).

${ }^{13} \mathrm{C}\left\{{ }^{1} \mathrm{H}\right\}$ NMR $\left(\mathrm{CDCl}_{3}, \mathrm{~T}=243 \mathrm{~K}, \mathrm{ppm}\right) \delta: 54.1\left(\mathrm{CH}_{2}, \mathrm{CH}_{2} \mathrm{Ph}\right), 63.0$ $\left(\mathrm{CH}_{2}, \mathrm{NCH}_{2} \mathrm{~N}\right), 63.6\left(\mathrm{CH}, \mathrm{CH}^{\mathrm{nq}}\right), 120.5\left(\mathrm{CH}, \mathrm{CH}^{\mathrm{Im}}\right), 121.1\left(\mathrm{CH}, \mathrm{CH}^{\mathrm{Im}}\right)$, 124.9-138.9 ( $\mathrm{Ph}), 180.5$ (C, C=O), 181.4 (C, carbene).

Anal. Calc. for $\mathrm{C}_{31} \mathrm{H}_{26} \mathrm{~N}_{4} \mathrm{O}_{2} \mathrm{Pd}: \mathrm{C}, 62.79 ; \mathrm{H}, 4.42 ; \mathrm{N}, 9.45$. Found: C, $62.91 ; \mathrm{H}, 4.33 ; \mathrm{N}, 9.38 \%$.

IR $(\mathrm{KBr}): v_{\mathrm{C}=\mathrm{O}}=1600,1559,1683 \mathrm{~cm}^{-1}$.

Derivatives $4 \mathbf{e}$ and $4 \mathbf{f}$, were prepared in a similar way using the appropriate reactants.

The color of the complexes, the reaction time and the yield are reported at the top of each characterization.

\subsection{Synthesis of the tmetc complex $\mathbf{4 e}$}

Brown microcrystals, 60 min, yield $65 \%$.

${ }^{1} \mathrm{H}$ NMR $\left(300 \mathrm{MHz}, \mathrm{CDCl}_{3}, T=298 \mathrm{~K}, \mathrm{ppm}\right) \delta: 3.50(\mathrm{~s}, 12 \mathrm{H}$, $\left.4 \mathrm{OCH}_{3}\right), 5.60\left(\mathrm{~s}, 4 \mathrm{H}, 2 \mathrm{CH}_{2} \mathrm{Ph}\right), 5.84\left(\mathrm{~s}, 2 \mathrm{H}, \mathrm{NCH}_{2} \mathrm{~N}\right), 6.80(\mathrm{bd}, 2 \mathrm{H}$, $\left.2 \mathrm{CH}^{\mathrm{Im}}\right), 7.12\left(\mathrm{bd}, 2 \mathrm{H}, 2 \mathrm{CH}^{\mathrm{Im}}\right), 7.25-7.37(\mathrm{~m}, 10 \mathrm{H}, 2 \mathrm{Ph})$.

${ }^{13} \mathrm{C}\left\{{ }^{1} \mathrm{H}\right\}$ NMR $\left(\mathrm{CDCl}_{3}, T=243 \mathrm{~K}, \mathrm{ppm}\right) \delta: 50.9\left(\mathrm{CH}_{3}, \mathrm{OCH}_{3}\right), 53.8$ $\left(\mathrm{CH}_{2}, \mathrm{CH}_{2} \mathrm{Ph}\right), 62.9\left(\mathrm{CH}_{2}, \mathrm{NCH}_{2} \mathrm{~N}\right), 120.0\left(\mathrm{CH}, \mathrm{CH}^{\mathrm{Im}}\right), 120.6(\mathrm{CH}$, $\left.\mathrm{CH}^{\mathrm{Im}}\right), 128.4-136.1(\mathrm{Ph}), 167.8\left(\mathrm{COOCH}_{3}\right), 181.4$ (C, carbene).

Anal. Calc. for $\mathrm{C}_{31} \mathrm{H}_{32} \mathrm{~N}_{4} \mathrm{O}_{8} \mathrm{Pd}$ : C, 53.57; $\mathrm{H}, 4.64 ; \mathrm{N}, 8.06$. Found: C, 53.72; H, 4.67; N, 7.94\%.

$\operatorname{IR}(\mathrm{KBr}): v_{\mathrm{C}=\mathrm{O}}=1712,1666 \mathrm{~cm}^{-1}, v_{\mathrm{C}-\mathrm{O}}=1239 \mathrm{~cm}^{-1}$.

\subsection{Synthesis of the dmfu complex $\mathbf{4 f}$}

Brown microcrystals, 60 min, yield 64\%.

${ }^{1} \mathrm{H}$ NMR (300 MHz, $\left.\mathrm{CD}_{2} \mathrm{Cl}_{2}, T=298 \mathrm{~K}, \mathrm{ppm}\right) \delta: 3.31(\mathrm{~s}, 6 \mathrm{H}$, $\left.2 \mathrm{OCH}_{3}\right), 3.56\left(\mathrm{~s}, 2 \mathrm{H}, 2 \mathrm{CH}^{\mathrm{dmfu}}\right), 5.36-5.53$ (AB system, $4 \mathrm{H}$, $\left.J=14.5 \mathrm{~Hz}, 2 \mathrm{CH}_{2} \mathrm{Ph}\right), 5.91\left(\mathrm{~s}, 2 \mathrm{H}, \mathrm{NCH}_{2} \mathrm{~N}\right), 6.90(\mathrm{~d}, 2 \mathrm{H}, J=1.6 \mathrm{~Hz}$, $\left.2 \mathrm{CH}^{\mathrm{Im}}\right), 7.10\left(\mathrm{~d}, 2 \mathrm{H}, J=1.6 \mathrm{~Hz}, 2 \mathrm{CH}^{\mathrm{Im}}\right), 7.33-7.43(\mathrm{~m}, 10 \mathrm{H}, 2 \mathrm{Ph})$.

${ }^{13} \mathrm{C}\left\{{ }^{1} \mathrm{H}\right\} \operatorname{NMR}\left(\mathrm{CD}_{2} \mathrm{Cl}_{2}, T=243 \mathrm{~K}, \mathrm{ppm}\right) \delta: 38.7\left(\mathrm{CH}, \mathrm{CH}^{\mathrm{dmfu}}\right), 50.4$ $\left(\mathrm{CH}_{3}, \mathrm{OCH}_{3}\right), 55.3\left(\mathrm{CH}_{2}, \mathrm{CH}_{2} \mathrm{Ph}\right), 63.3\left(\mathrm{CH}_{2}, \mathrm{NCH}_{2} \mathrm{~N}\right), 119.2(\mathrm{CH}$, $\left.\mathrm{CH}^{\mathrm{Im}}\right), 121.2\left(\mathrm{CH}, \mathrm{CH}^{\mathrm{Im}}\right), 128.0-137.3(\mathrm{Ph}), 176.9(\mathrm{C}, \mathrm{C}=\mathrm{O}), 187.4$ (C, carbene).

Anal. Calc. for $\mathrm{C}_{27} \mathrm{H}_{28} \mathrm{~N}_{4} \mathrm{O}_{4} \mathrm{Pd}$ : C, 56.01; $\mathrm{H}, 4.87 ; \mathrm{N}, 9.68$. Found: C, $56.17 ; \mathrm{H}, 5.02 ; \mathrm{N}, 9.53 \%$.

IR (KBr): $v_{\mathrm{C}=\mathrm{O}}=1712,1666 \mathrm{~cm}^{-1}, v_{\mathrm{C}-\mathrm{O}}=1239 \mathrm{~cm}^{-1}$. 


\section{Appendix A. Supplementary data}

Supplementary data associated with this article can be found, in the online version, at https://doi.org/10.1016/j.poly.2018.08.007.

\section{References}

[1] E. Negishi, Handbook of Organopalladium Chemistry for Organic Synthesis, (Sect I.2), John Wiley and Sons, New York, 2002.

[2] J. Tsuji, Palladium Reagents and Catalysis, John Wiley and Sons, Chichester, 1995.

[3] (a) J.-Y. Lee, J.-S. Shen, R.-J. Tzeng, I.-C. Lu, J.-H. Lii, C.-H. Hu, H.M. Lee, Dalton Trans. 45 (2016) 10375;

(b) Y.-M. Jhou, D. Nandi, J.-Y. Lee, R.J. Tzeng, H.M. Lee, Polyhedron 100 (2015) 28; (c) M.B. Ansell, D.E. Roberts, F.G.N. Cloke, O. Navarro, J. Spencer, Angew. Chem., Int. Ed. 54 (2015) 5578;

(d) P. Nägele, U. Herrlich, F. Rominger, P. Hoffman, Organometallics 32 (2013) 181;

(e) D. Krishnan, M. Wu, M. Chiang, Y. Li, P.-H. Leung, S.A. Pullarkat Organometallics 32 (2013) 2389;

(f) J.-Y. Lee, P.-Y. Cheng, Y.-H. Tsai, G.-R. Lin, S.-P. Liu, M.-H. Sie, H.M. Lee, Organometallics 29 (2010) 3901;

(g) S. Warsink, I.-H. Cahng, J.J. Weigand, P. Hauwert, J.-T. Chen, C.J. Elsevier, Organometallics 29 (2010) 4555;

(h) E.M. Prokopchuck, R.J. Puddhephatt, Organometallics 22 (2003) 563;

(i) T.M. Trnka, R.H. Grubbs, Acc. Chem. Res. 34 (2001) 18;

(j) T. Weskamp, V.P. Bohm, W.A. Hermann, J. Organomet. Chem. 600 (2000) 12;

(k) L. Jafapour, S.P. Nolan, Adv. Organomet. Chem. 46 (2000) 181.

[4] (a) D.S. McGuinness, W. Mueller, P. Wasserscheid, K.J. Cavell, B.W. Skelton, A H. White, Organometallics 21 (2002) 175;

(b) D.J. Nielsen, K.J. Cavell, B.W. Skelton, A.H. White, Inorg. Chim. Acta 327 (2002) 116;

(c) R.E. Doutwhite, M. Green, P.J. Silkock, P.T. Gomes, J. Chem. Soc. Dalton Trans. (2002) 1386;

(d) W.A. Hermann, L.J. Goossen, M. Spiegler, Organometallics 17 (1998) 2162

[5] (a) F. Visentin, A. Togni, Organometallics 26 (2007) 3746;

(b) A.W. Waltman, R.H. Grubbs, Organometallics 23 (2004) 3105;

(c) H. Seo, H. Park, B.Y. Kim, J.H. Lee, Y.K. Chung, Organometallics 22 (2003) 618;

(d) M. Freseth, A. Dhindsa, H. Røise, M. Tilset, J. Chem. Soc. Dalton Trans (2003) 4516;

(e) L.G. Bonnet, R.E. Doutwhite, B.M. Kariuki, Organometallics 22 (2003) 4187; (f) A.A.D. Tulloch, S. Winston, A.A. Danoupolos, G. Eastham, M.B. Hursthouse, J. Chem. Soc. Dalton Trans. (2003) 699;

(g) A.A.D. Tulloch, A.A. Danopoulos, S. Khleinhenz, M.E. Light, M.B. Hursthouse, G. Eastham, Organometallics 20 (2000) 2027;

(h) A.A.D. Tulloch, A.A. Danoupolos, S. Winston, S. Khleinhenz, G. Eastham, J Chem. Soc. Dalton Trans. (2000) 4499.

[6] (a) A.J. Arduengo, R.L. Harllow, M.J. Kline, J. Am. Chem. Soc. 113 (1991) 361; (b) A.J. Arduengo, H.V.R. Dias, J.C. Calabrese, F. Davidson, J. Am. Chem. Soc. 114 (1992) 5530;

(c) A.J. Arduengo, H.V.R. Dias, J.C. Calabrese, F. Davidson, J. Am. Chem. Soc. 114 (1992) 9724.

[7] (a) W.A. Hermann, M. Elison, J. Fisher, C. Knoker, G.R.J. Artus, Angew. Chem. Int. Ed. 34 (1995) 2371;

(b) M. Muehlhofer, T. Strassern, W.A. Hermann, Angew. Chem., Int. Ed. 41 (2002) 1745; (c) H.M. Lee, C.Y. Lu, C.Y. Chen, W.L. Chen, H.C. Lin, P.L. Chiu, P.Y. Chen, Tetrahedron 64 (2004) 5807;

(d) A. Biffis, M. Cipani, E. Bressan, C. Tubaro, C. Graiff, A. Venzo, Organometallics 33 (2014) 2182;

(e) D. Munz, T. Strassner, Angew. Chem., Int. Ed. 53 (2014) 2485;

(f) S.P. Desai, M. Mondal, J. Choudhury, Organometallics 34 (2015) 2731;

(g) D. Zang, Y. He, J. Tang, Dalton Trans. 45 (2016) 11699;

(h) C. Barthes, C. Bijani, N. Lungan, Y. Canac, Organometallics 37 (2018) 673.

[8] (a) I.E. Marko, S. Sterin, O. Buisine, G. Mignani, P. Branlard, B. Tinant, J.-P. Declercq, Science 298 (2002) 204;

(b) I.E. Marko, S. Sterin, O. Buisine, G. Berthon, G. Michaud, B. Tinant, J.-P. Declercq, Adv. Synth. Catal. 346 (2004) 1429;

(c) P. Hauwert, G. Maestri, J.W. Sprengers, M. Catellani, C.J. Elsevier, Angew. Chem., Int. Ed. 47 (2008) 3223;

(d) M. Brendel, C. Braun, F. Rominger, P. Hofmann, Angew. Chem., Int. Ed. 53 (2014) 8741;

(e) L. Canovese, F. Visentin, T. Scattolin, C. Santo, V. Bertolasi, Polyhedron 144 (2018) 131.

[9] (a) S.N. Sluijter, S. Warsink, M. Lutzc, C.J. Elsevier, Dalton Trans. 42 (2013) 7365;

(b) S. Warsink, P. Hauwert, M.A. Siegler, A.L. Spek, C.J. Elsevier, Appl. Organometal. Chem. 23 (2009) 225.

[10] L. Canovese, F. Visentin, Inorg. Chim. Acta 363 (2010) 2375.

[11] (a) L. Canovese, F. Visentin, G. Chessa, P. Uguagliati, A. Dolmella, J. Organomet. Chem 601 (2000) 1;

(b) L. Canovese, F. Visentin, P. Uguagliati, B. Crociani, J. Chem. Soc., Dalton Trans. (1996) 1921.

[12] L. Canovese, C. Santo, F. Visentin, Organometallics 27 (2008) 3577.

[13] L. Canovese, F. Visentin, C. Biz, T. Scattolin, C. Santo, V. Bertolasi, Polyhedron $102(2015) 94$

[14] (a) Y.A. Wanniarachchi, M.A. Khan, L.M. Slaughter, Organometallics 23 (2004) 5881 ;

(b) Y. Cheng, X.-Y. Lu, H.-J. Xu, Y.-Z. Li, X.-T. Chen, Z.-L. Xue, Inorg. Chim. Acta 363 (2010) 430;

(c) C.A. Quezada, J.C. Garrison, M.J. Panzner, C.A. Tessier, W.J. Youngs, Organometallics 23 (2004) 4846.

[15] L. Canovese, F. Visentin, G. Chessa, P. Uguagliati, G. Bandoli, Organometallics 24 (2005) 3297.

[16] A.C. Brown, L.A. Carpino, J. Org. Chem. 50 (1985) 1749.

[17] L. Farrugia, WinGX and ORTEP for Windows: an Update, J. Appl. Crystallogr. 45 (4) (2012) 849

[18] J. Yu, J.B. Spencer, J. Am. Chem. Soc. 119 (1997) 5257.

[19] (a) T.A.P. Paulose, S.-C. Wu, J.A. Olson, T. Chau, N. Theaker, M. Hassler, J.W. Quail, S.R. Foley, Dalton Trans. 41 (2012) 251;

(b) H.M. Lee, C.Y. Lu, C.Y. Chen, W.L. Chen, H.C. Lin, P.L. Chiu, P.Y. Cheng, Tetrahedron 60 (2004) 5807

[20] T. Fujihara, Y. Obora, M. Tokunaga, Y. Tsuji, Dalton Trans. (2007) 1567.

[21] A. Laus, M. Polentarutti, S. Onesti, J.R. Plaisier, E. Busetto, G. Bais, L. Barba, A. Cassetta, G. Campi, D. Lamba, A. Pifferi, S.C. Mande, D.D. Sarma, S.M. Sharma, G. Paolucci, Eur. Phys. J. Plus 130 (2015) 1

[22] K. Kabsch, XDS, Acta Crystallogr., Sect. D 66 (2010) 125.

[23] G.M. Sheldrick, SADABS, University of Göttingen, Germany, 2012.

[24] G.M. Sheldrick, Acta Crystallogr., Sect. A 71 (2015) 3.

[25] A.L. Spek, Acta Crystallogr., Sect. D 65 (2009) 148.

[26] G.M. Sheldrick, Acta Crystallogr., Sect. C 71 (2015) 3.

[27] P. Emsley, B. Lohkamp, W. Scott, K. Cowtan, Acta Crystallogr., Sect. D 66 (2010) 486.

[28] L. Schrodinger, The Pymol Molecular Graphics System, Schrodinger, LLC, 2015. 